\title{
Strobilanthes barbigera (Acanthaceae), a new species from Vietnam
}

\author{
John R. I. Wood ${ }^{1,2}$, Maxim S. Nuraliev ${ }^{3,4}$, Andrey N. Kuznetzov ${ }^{3,5}$, Svetlana P. Kuznetzova ${ }^{3}$ \& \\ R. W. Scotland ${ }^{1}$
}

Summary. A. new species of Strobilanthes, S. barbigera J. R. I. Wood, Nuraliev \& Scotland, is described from Vietnam. The new species is endemic to the Chu Yang Sin National Park in the southern part of the country, which is home to a number of other recently described species. S. barbigera belongs to the "Sympagis" group within Strobilanthes and its distinctive pollen is illustrated. Photographs and line drawings illustrate the new species.

Key Words. Chu Yang Sin National Park, pollen, taxonomy.

\section{Introduction}

Strobilanthes Blume consists of around 400 species distributed widely throughout India, South China and SE Asia, extending to Afghanistan in the west, Japan in the northeast and New Guinea to the south. Species mostly occur in hill forest in areas with a seasonal monsoon climate, fewer species being found in the true rainforest of the Malay Peninsula or Borneo. Many species are remarkable for their plietesial flowering pattern, which partially explains why many species are rarely collected and poorly known. However, they are sometimes an important element in the forest understorey and may unexpectedly appear in great abundance in a flowering year.

The Strobilanthes flora of Vietnam is not very well documented. The richest area appears to be along the Chinese border in the north of the country. Further south there appear to be fewer species and those that do occur are poorly known. Amongst species endemic or near endemic to the southern part of Vietnam are S. saltiensis $\mathrm{S}$. Moore, S. longipedunculata Terao ex J. R. I. Wood, S. hypomalla Benoist (also on the Bolaven Plateau in Laos) and the new species described below from the Chu Yang Sin National Park. This park was established in 2002 and covers an area of nearly 600 square kilometres. The park is mountainous and its highest peak is over $2400 \mathrm{~m}$ high. The lower slopes are covered in semi-evergreen forest but the middle altitudes where the Strobilanthes grows are covered in montane mixed evergreen forest. Its flora is not very well known but it is home to a number of Vietnamese endemics including Vietorchis furcata Aver. \& Nuraliev and Thismia puberula Nuraliev, both described from a site close to that of S. barbigera (Averyanov et al. 2013; Nuraliev et al. 2015), as well as Aspidistra paucitepala Vislobokov, Nuraliev \& D. D. Sokoloff and Thismia mucronata Nuraliev, described from other localities but later found in Chu Yang Sin National Park.

\section{Materials and Methods}

This study is based on field work by Nuraliev, Kuznetzov and Kuznetzova in Vietnam combined with studies of herbarium material in Oxford and Kew. Acetolysed pollen was examined using a Scanning Electron Microscope.

\section{Taxonomic Treatment}

Strobilanthes barbigera J. R. I. Wood, Nuraliev $\mathcal{E}$ Scotland, sp. nov. Type: Vietnam (southern part), Dak Lak Province, Lak Distr.; Mun. Bong Krang, Chu Yang Sin National Park, $11 \mathrm{~km} \mathrm{~S}$ of Krong Kmar Village, $12^{\circ} 23^{\prime} 15^{\prime} \mathrm{N} 108^{\circ} 20^{\prime} 45^{\prime \prime E}, 1300$ m, 13 April 2012, M. S. Nuraliev 543 (holotype FHO, isotype MW).

http://www.ipni.org/urn:lsid:ipni.org:names:60474134-2

Perennial herb, anisophyllous; stems weakly zigzag, glabrous, sulcate. Leaves unequal in each pair, the

\footnotetext{
Accepted for publication 25 April 2017. Published online 17 May 2017

1 Department of Plant Sciences, University of Oxford, South Parks Road, Oxford, OX1 3RB, UK. e-mail: jriwood@hotmail.com

2 Honorary Research Associate, Royal Botanic Gardens, Kew, Richmond, Surrey, TW9 3AB, UK.

3 Joint Russian-Vietnamese Tropical Scientific and Technological Center, Cau Giay, Hanoi, Vietnam.

4 Faculty of Biology, M.V. Lomonosov Moscow State University, 1, 12, Leninskie Gory, 119234, Moscow, Russia.

${ }^{5}$ A.N. Severtsov Institute of Ecology and Evolution of the Russian Academy of Sciences, Leninsky, 33, Moscow, Russia.
} 
smaller about half the larger, petiolate, $2.5-10.5 \times 2-$ $4 \mathrm{~cm}$, oblong-elliptic, apex acuminate, sometimes falcate, base slightly asymmetric, attenuate to cuneate, slightly decurrent, margin crenate; both surfaces glabrous, cystoliths present; adaxially often with prominent whitish blotches arranged in two lines on either side of the midrib; abaxially paler; veins $6-7$ pairs; petioles $0.6-1.8 \mathrm{~cm}$, glabrous. Inflorescence branched, capitellate, the flowers in few-flowered bracteate heads at apex of the branchlets; peduncles axillary, often trifurcate, $2.5-6 \mathrm{~cm}$; inflorescence branches c. $4 \mathrm{~cm}$, glabrous but cystoliths prominent; bracts at inflores- cence branching points, shortly petiolate, $4-8 \times 4-8$ $\mathrm{mm}$, ovate to suborbicular, rounded to obtuse, cystoliths present, glabrous, eventually caducous, petioles 1 $-2 \mathrm{~mm}$; bracts subtending heads similar but sessile and often obovate, obtuse and somewhat caducous, pedicels $0-1 \mathrm{~mm}$, glabrous; floral bracts $8-11 \times 3-3.5$ $\mathrm{mm}$, obovate, sessile, persistent, abaxially with stipitate glands at anthesis, somewhat accrescent in fruit, whitepilose from the elongate glands; bracteoles $8-10 \times 2-3$ $\mathrm{mm}$, spathulate, persistent, abaxially with stipitate glands at anthesis, somewhat accrescent in fruit, white-pilose from the elongated glands (Fig. 1A - B).
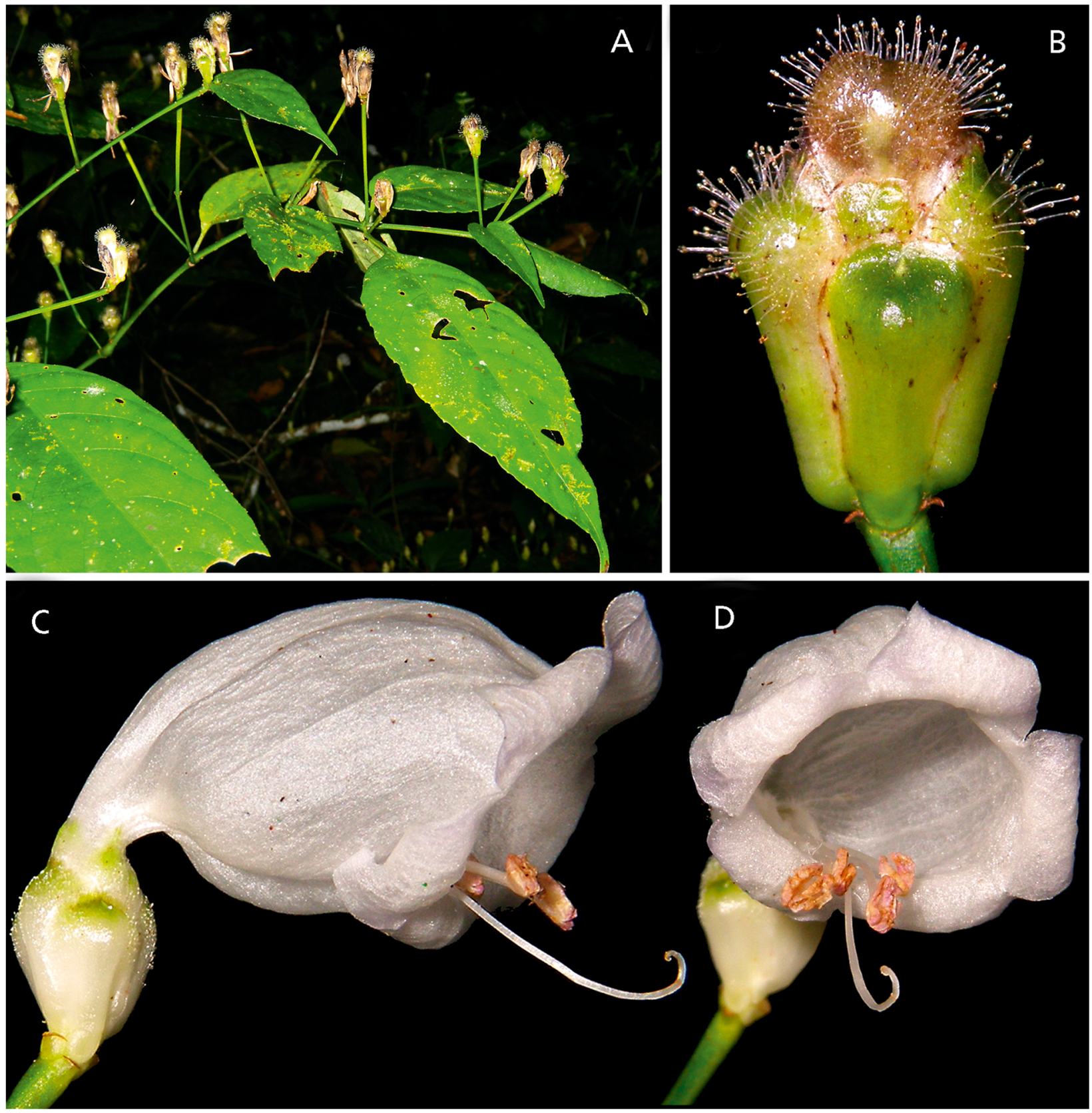

Fig. 1. Strobilanthes barbigera (Nuraliev 543). A branch showing inflorescence in fruit; B head post anthesis; C corolla and calyx, side view; D corolla, front view. PHOTOS: MAXIM NURALIEV. 

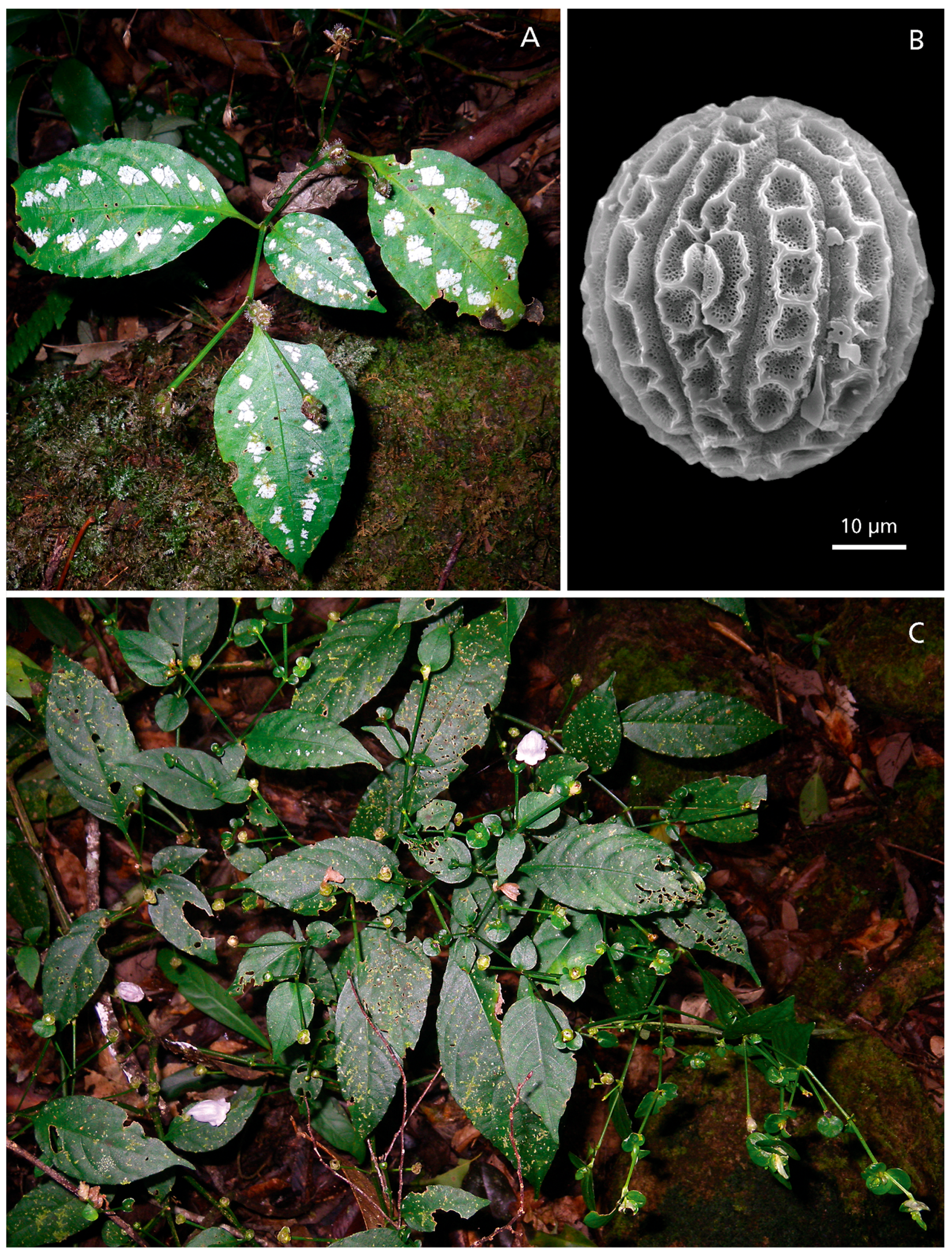

Fig. 2. Strobilanthes barbigera. A branch showing spotted leaves and fruiting inflorescence (Nuraliev 506); B pollen grain, side view (SEM image from Nuraliev 543); C plant with flowering and pre-flowering heads (Nuraliev 543); note partial spotting on leaves, centre left. PHOTOS: MAXIM NURALIEV. 
Calyx subequally 5-lobed to base, lobes $7 \times 1 \mathrm{~mm}$, linear-oblong, accrescent to $9 \times 1.5 \mathrm{~mm}$ in fruit and becoming linear-oblanceolate, apex obtuse or retuse, glabrous, abaxially whitish-green through abundant cystoliths. Corolla c. $1.6 \mathrm{~cm}$ long, the tube whitish but lobes pale blue, glabrous on the exterior, interior glabrous except for short hairs retaining the style, basal tube widened from $2 \mathrm{~mm}$ to $4 \mathrm{~mm}$ for c. $4 \mathrm{~mm}$, then bent and abruptly widened to c. $10 \mathrm{~mm}$ at mouth, lobes 5, slightly unequal, ovate, rounded, c. $2.5 \mathrm{~mm}$ long and broad; stamens 4, didynamous, inserted at base of inflated part of corolla, all fertile, two longer exserted at anthesis, the two shorter included (Fig. 1C - D); filaments shortly pilose, shorter pair $2.5 \mathrm{~mm}$ long, longer pair $3.5 \mathrm{~mm}$ long; anthers erect, broadly oblong, $2 \times 1.25 \mathrm{~mm}$, muticous, outer pair facing opposite direction to inner pair; pollen c. $50 \mu \mathrm{m}$ diam., spheroidal, triporate, sexine forming raised narrow longitudinal flanges with transverse ridges creating a subscalariform pattern (Fig. 2B); style $13 \mathrm{~mm}$, glabrous, included; ovary c. 1.5 $\mathrm{mm}$, comose. Capsule oblong in outline, $10 \times 3 \mathrm{~mm}$, glabrous apart from a few apical hairs, 4-seeded; seeds lenticular, flattened, $2.25 \times 2 \mathrm{~mm}$, pilose with appressed mucilagineous hairs; areole small. Figs $1-3$.

RECOGNITION. This species shows several characteristics of the "Sympagis" group of Strobilanthes as defined by Wood et al. (2003: 133), having in particular capitellate inflorescences, persistent floral bracts, small corolla

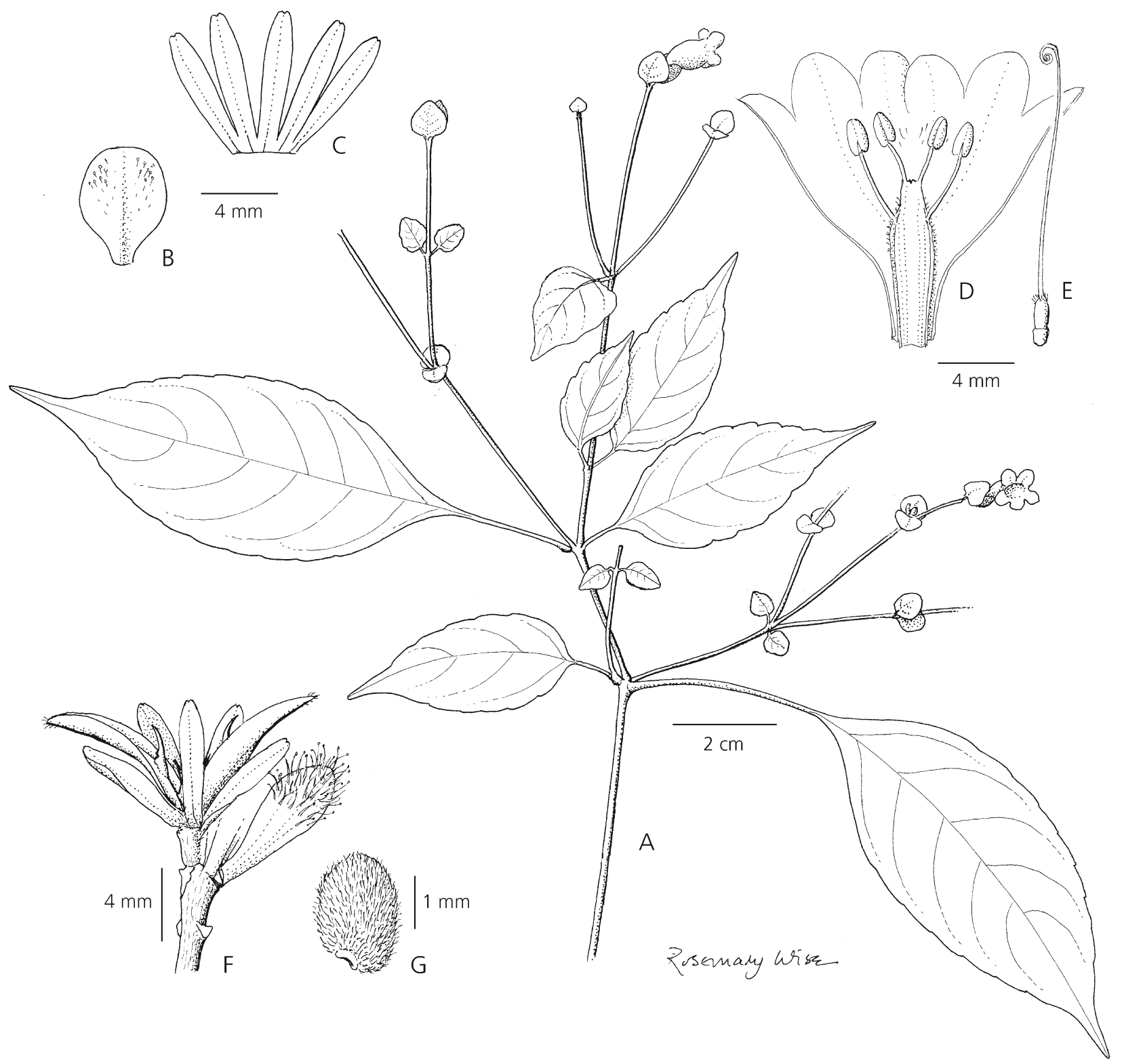

Fig. 3. Strobilanthes barbigera A habit; B floral bract; C calyx; D corolla opened out to show stamens; E ovary and style; F fruiting inflorescence showing pilose bracteole capsule; G seed. A - E from Nuraliev 543, F - G from Nuraliev 457. DRAWN BY ROSEMARY WISE. 
with exserted stamens and a subequally 5-lobed calyx. This placement is confirmed by examination of its pollen which is typical of this group (Fig. 2B) and closely resembles that of $S$. alata Blume (Bennett \& Scotland 2003: 12) and S. serrata J. B. Imlay, treated as Type 12 in the Flora of China (Hu et al. 2011: 382). Amongst species placed in the "Sympagis" group it is superficially similar to the Javanese species, S. alata (Bennett \& Scotland 2003: 49 - 50) not only in pollen but also in gross morphology, particularly in the $3-5$ flowered capitellate inflorescences with persistent obovate floral bracts and bracteoles borne on axillary, often trifurcate peduncles. It differs markedly in lacking winged stems and peduncles, the presence of prominent accrescent hairs on the abaxial surface of the floral bracts and bracteoles and in the comose ovary and capsule. Amongst Vietnamese species it is most similar to S. paniculata (Nees) Miq., particularly in its tendency to have obtuse to retuse calyx lobes but differs in the spheroidal, not ellipsoidal pollen, suborbicular to broadly ovate floral bracts and the distinctive hirsute bracteoles in fruit. The tendency to have blotched leaves is also shared by another species in this group, S. maculata (Wall.) Nees, but the spicate inflorescence of that species is very different.

HABITAT \& DISTRIBUTION. Primary evergreen broadleaved and mixed humid forest on levelled terraces of mountain slopes composed of silicate mother rocks with scattered granite outcrops. Canopy trees are $22-24 \mathrm{~m}$ high consisting principally of Illicium L. (Schisandraceae), Manglietia Blume, Michelia T. Durand (Magnoliaceae), Cinnamomum Schaeff. (Lauraceae), Exbucklandia R. W. Br., Rhodoleia Champ. ex Hook. (Hamamelidaceae), Altingia Noronha (Altingiaceae), Elaeocarpus L. (Elaeocarpaceae), Schefflera J. R. Forst. \& G. Forst.(Araliaceae), as well as the conifers Dacrycarpus imbricatus (Blume) de Laub. and Podocarpus neriifolius D. Don (Podocarpaceae). The new species is known from two populations between $1300-1650 \mathrm{~m}$ with a distance of $1.3 \mathrm{~km}$ between them. Both are located in shaded ravines along small streams. In one of the known locations (M. S. Nuraliev 543) Strobilanthes barbigera cooccurs with $S$. echinata Nees. Late flowering and fruiting was observed in April.

SPECIMENS SEEN. VIETNAM: Dak Lak Province, Lak Distr.; Mun. Bong Krang, Chu Yang Sin National Park, $14 \mathrm{~km} \mathrm{~S}$ of Krong Kmar Village, $12^{\circ} 22^{\prime} 41^{\prime} \mathrm{N}$ 108 21'09"E, 1640 m, 2 April 2012, M. S. Nuraliev 457 fr. (FHO, MW); ibid., 9 April 2012, M. S. Nuraliev 506 fr. (FHO, MW); ibid., $11 \mathrm{~km} \mathrm{~S}$ of Krong Kmar Village, $12^{\circ} 23^{\prime} 15^{\prime} \mathrm{N} 108^{\circ} 20^{\prime} 45^{\prime \prime E}, 1300 \mathrm{~m}, 13$ April 2012, M. S. Nuraliev 543 fl. (FHO, MW).
CONSERVATION STATUS. Data deficient. At the present time this species is known from two populations in a protected area, one of these, that at a higher altitude, consisted of numerous individuals along a stream over a distance of 50 to $100 \mathrm{~m}$.

NOTES. The filament curtain is unusual in this species in having very short hairs.

EPONYMY. The epithet "barbigera" refers to the prominent long white glandular hairs that develop on the abaxial surface of the bracteoles as they age (Fig. 1B, 3).

\section{Acknowledgements}

Thanks are due to Rosemary Wise for preparing the illustration. The work of M. S. Nuraliev was carried out in accordance to Government order for the Lomonosov Moscow State University Project No. AAAA-A16-116021660105-3.

Open Access This article is distributed under the terms of the Creative Commons Attribution 4.0 International License (http://creativecommons.org/ licenses/by/4.0/), which permits unrestricted use, distribution, and reproduction in any medium, provided you give appropriate credit to the original author(s) and the source, provide a link to the Creative Commons license, and indicate if changes were made.

\section{References}

Averyanov, L. V., Nuraliev, M. S., Kuznetsov, A. N. \& Kuznetsova, S. P. (2013). Vietorchis furcata (Orchidaceae, Vietorchidinae) - a new species from Southern Vietnam. Taiwania 58 (4): 251 256, 2013. DOI: $10.6165 /$ tai.2013.58.251

Bennett, J. R. \& Scotland, R. W. (2003). A revision of Strobilanthes (Acanthaceae) in Java. Kew Bull. 58: 1 82.

Hu, C. C., Deng, Y. F., Wood, J. R. I. \& Daniel, T. F. (2011). Acanthaceae. In: Flora of China 19: 369 - 477. Harvard University Press, Cambridge, Mass.

Nuraliev, M., Beer, A., Kuznetsov, A. \& Kuznetsova, S. (2015). Thismia puberula (Thismiaceae), a new species from Southern Vietnam. Phytotaxa 234 (2): 133 - 142.

Wood, J. R. I., Bennett, J. R. \& Scotland, R. W. (2003). Notes on Strobilanthes: the Sympagis group. Kew Bull. 58: 131 - 173 . 